\title{
Academic Library Buildings: A Century in Review
}

$\mathbf{I}_{\mathrm{r}}$

IS APPROPRIATE that following ten years of unprecedented expansion of academic library building we should pause to review the experience of a century in this aspect of our country's development. Just as 1876 was a banner year for landmark events in the library world of that time, 1976 will soon be read as a key year to mark the close of one glorious century of change and the bellwether of good planning for the next. In the 1876 record one can discern the germination and early flowering of many library building planning ideas for the century ahead.

In his introductory essay for this centennial series, Edward G. Holley briefly sketched the academic library building scene in 1876. He neatly recorded and characterized the notable libraries of that time. ${ }^{1}$ Few institutions had separate buildings designed exclusively for library use. Harvard, Yale, Princeton (then the College of New Jersey), Rochester, and Brown were among the best known. Mount Holyoke and Wellesley were reported as having distinctive library space. Most of the smaller institutions had what is often described as the library "apartment," consisting of one or more rooms in a school building serving a variety of functions.

In the 1876 report of the Bureau of Education, a landmark source for all library history, one finds a list of seventyone principal academic libraries. ${ }^{2}$ Only eight of these had more than 30,000 volumes in 1876. Forty-nine, more than two-thirds of the list, possessed fewer than 20,000 volumes. One-third of the seventy-one reported 10,000 volumes or less. These statistics alone suggest little need for separate or very extensive library space.

Another view of academic libraries in 1876 as shown in that list reveals that fifteen of the twenty largest reported libraries were in private institutions. Of the twenty claiming more than 20,000 volumes, only five were public institutions, and only one of the eight largest collections was in a public institution. At least in size of collections, the preeminence of private academic libraries over those funded by publie moneys was evident.

Holley's paper records in detail other aspects of the educational system of 1876 having considerable bearing upon the state of library building at that time. The size and character of the student population, the numbers and qualifications of the faculty, the provision of library staff, the curriculumall of these as well as other factors surely influenced library development (or lack thereof) in academic institutions. The influence of society libraries was considerable. Teaching methodology of that time placed little emphasis on library reading or research, and the almost total lack of library staff certainly 
had its effect. The production and distribution of library materials then was vastly different from what we know today. Relatively few books were being published in the U.S., and procuring books from abroad was both difficult and costly. Library budgets were minuscule or nonexistent, and great dependence was laid upon begging from known potential donors and upon the assessing of small student library fees.

\section{The Begrnnings}

All of these factors conspired to create a climate for the development of academic libraries that could only improve. Reading the sparse literature of librarianship and academic history of the years up to 1876 , one reaches the conviction that leaders of academic institutions then perceived the "library" as a collection of books, not a building or a place.

The centennial year was really a starting point for many aspects of librarianship, including library planning and building. The earliest reports of ALA conferences reveal frequent discussions, often passionate, on numerous topics related to building planning. Fulllength illustrated papers began to appear in the Library Journal when new libraries were built; many smaller reports were made as their numbers increased. Some of the great names of the time recorded their views in print: Justin Winsor, W. F. Poole, A. van Name, Melvil Dewey, Frederic Vinton, R. A. Guild among others. An early synthesis of library planning of that period is found in C. C. Soule's eleven points of agreement, which appeared in $1891 .^{3}$

Almost from the start, prime topics of contention included interior design, light, heat, and ventilation. There was a sprinkling of disagreement on the functional versus the aesthetic, with librarians and architects in close combat; there was so little real understanding on both sides that the result was a standoff.
For the most part, a library before 1876 was usually planned as a lofty room, either with galleries on one or more levels around the perimeter, or with a series of double-faced bookshelves arranged to create alcoves based upon the outside walls with a reading space in the center between the rows of alcoves. Administrative functions were lodged almost at random, witness:

$\ldots$ inexperienced, though well-meaning, architects and building committees have erected library buildings that are little less than monstrosities. ... There was no place for the librarian to sit down, or even to hang his hat; there was no place for the library assistants to deposit their umbrellas or to wash their hands. In fact, there was not a single one of the many conveniences necessary for doing the work of the library-no place for unpacking, classifying and cataloging books; no place for labelling, numbering, repairing books; no place for reading or for anything except taking books from the shelves and handing them to applicants, or reversing the process. ... . The librarian drove a nail into a window casing upon which to hang his hat; he drove nails into the bookcases upon which the attendants hung their wraps; he put a table into one corner for his own seat, and into another for his cataloguers; he fixed up a dark basement for a reading room. . . . It is to be feared that there is more than one library in this country, fair without and impressive to look upon, but within as ill-contrived for its purposes as possibly can be. ${ }^{4}$

This castigation of the architect is extreme, but it must be said that there was often great provocation. Charles A. Cutter and R. R. Bowker, then editors of the Library Journal, published a hot exchange of opinion between librarians and architects in $1888 .{ }^{5}$ This was one of many contentions certainly not limited to that period of time. One extremely well-balanced dispassionate statement by an architect developed out of a talk at 
the 1891 conference of ALA by an architect, Normand S. Patton, of Chicago. ${ }^{6}$ A quite comparable treatment of this relationship appeared more than fifty years later in John E. Burchard's paper on postwar library buildings.? This kind of natural wisdom has no time.

The last twenty-five years of the nineteenth century can only be characterized as experimental for academic library planning. There was a growing appreciation of the prime considerations of good library planning, but no approved design pattern. There was evidence of the librarian's determination to have a share in planning with the architect and some acquiescence by architects, but no assurance of coordination. There was a growing understanding of environmental needs, temperature control, lighting, traffic patterns, and user access, but no accepted standards. Most important of all, there was an evident increase in professional concern, not just for more library space but for proper housing for the functions then recognized.

Brown University dedicated its new library on February 16, 1878, having enforced a close collaboration between librarians and architects to resolve the difficult problems of library planning. Built in the form of a cross, with a large center, it had a large reading room, thirty-five feet wide and sixtyeight feet high with two galleries running around it and into its wings. Each wing was octagonal and alcoved, also on three levels. Even a very detailed description, while it describes the book capacity of the new library $(15,000$ volumes) says nothing of the available seats.

The University of California was not long (1881) in following the lead of Brown with a large library and art gallery. The library, like Brown, had a central main reading area, rising fifty-seven feet to a high dome, with three levels in the main floor and two galleries. Entrance areas and the art gallery occupied the forward part of the building with the reading areas and book stock at the rear. Alcoves were used throughout the book stock areas.

In the University of Pennsylvania library (1888) there is found an early example of separation of the bookstack from the reading rooms and general user. The design is in two parts, with extraordinary space provided for staff and users in the main body and what was described as a "greenhouse-looking shed" designed to hold 455,616 volumes. This was nine times the number of volumes the library then owned.

In 1889 Yale University moved its library into a new building, Chittenden Hall, as one of the interim steps before the much later Sterling Library. The Chittenden Library replaced and was attached to the "Old Library," but the construction was reported as expedient, simply because "of the space available for the use of the library. .... The central part was already occupied by the old building; too good to be removed at present, but too poor a specimen of library architecture to be preserved and incorporated in our future building." The combined capacity of the two buildings was reported as 400,000 volumes, with seats for ninety readers.

Cornell, another in the list of the early principal libraries, also hit a new high in 1891, when it dedicated a building designed to hold 475,000 volumes and with seats in one reading room for 232 readers. Not one, but three bookstack areas were planned in this library, still using the cross as the core pattern, with a high vaulted reading room and another with book ranges in alcoves.

Northwestern's Orrington Lunt Library was announced in September 1892, but not completed until two years later. The building was more than a library. All of the second floor was used for lecture hall, assembly room, and 


\section{THREE GENERATIONS OF LIBRARIES AT NORTHWESTERN UNIVERSITY EVANSTON, ILLINOIS}

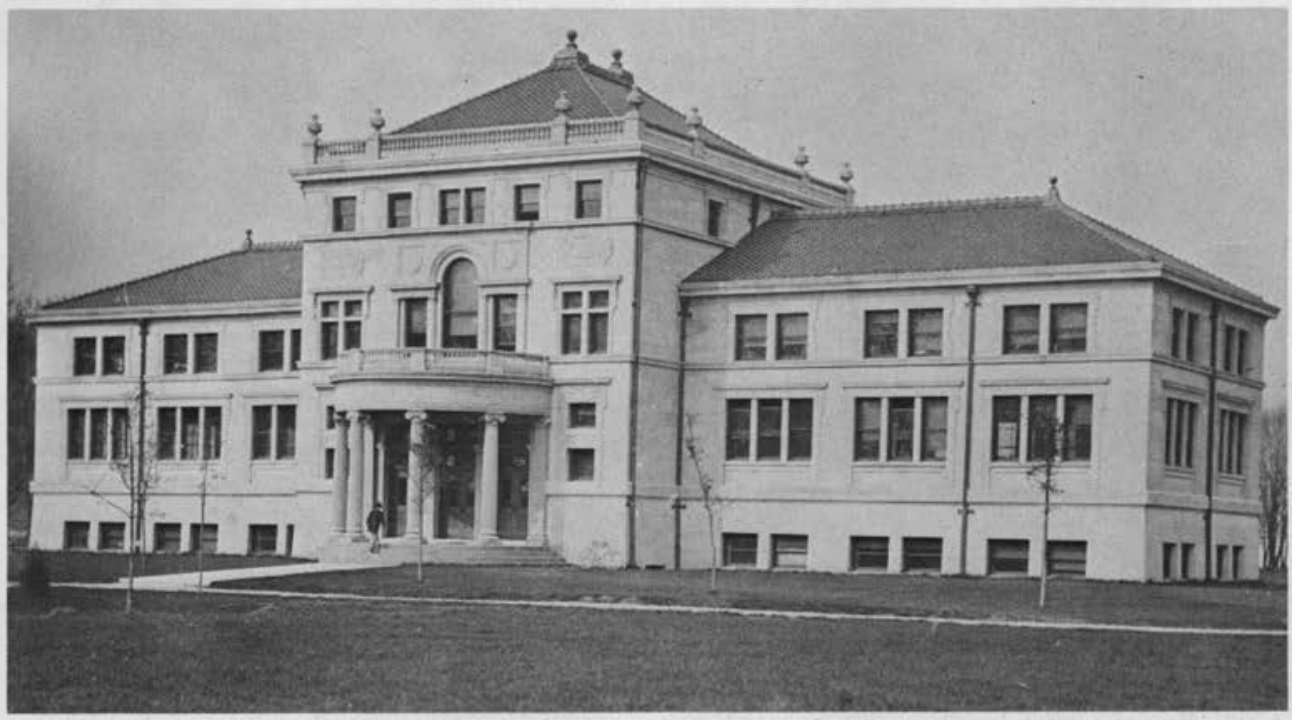

Orrington Lunt Library, 1894-1932

Northwestern University Archives

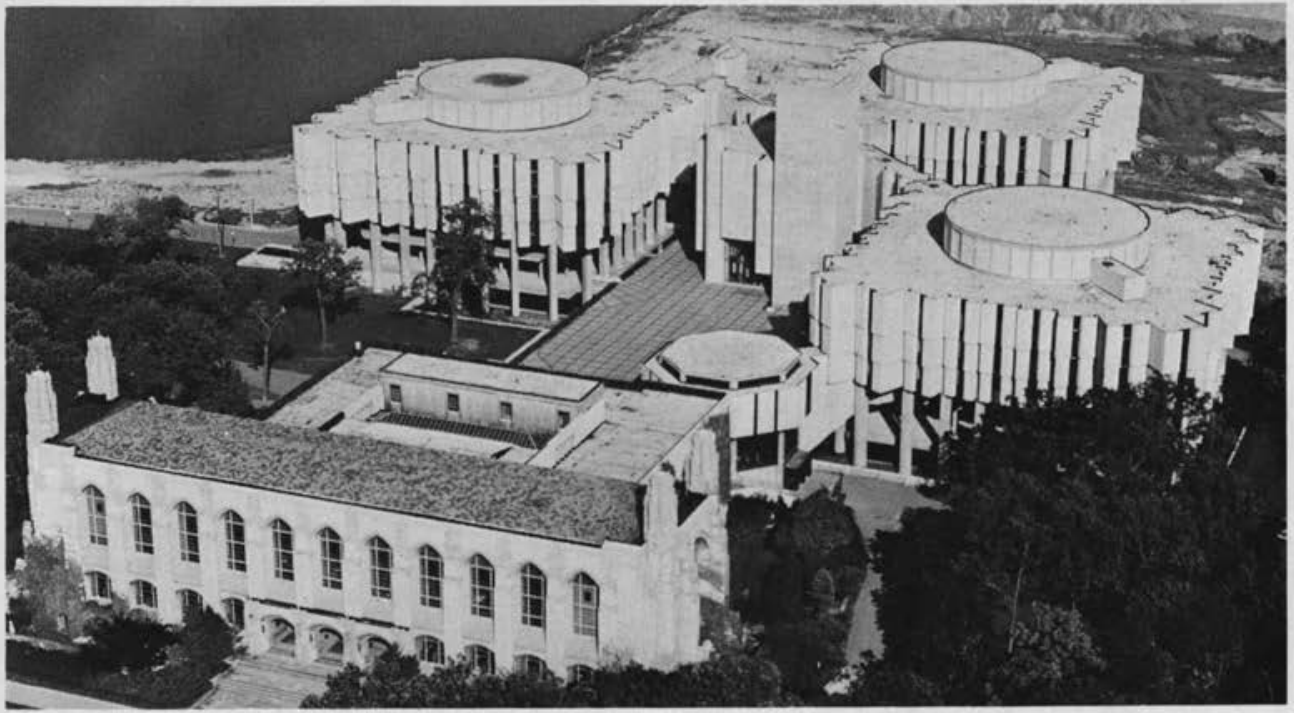

Charles Deering Library, 1932, in foreground connected

Northwestern University Archives with the Northwestern University Library, 1970 


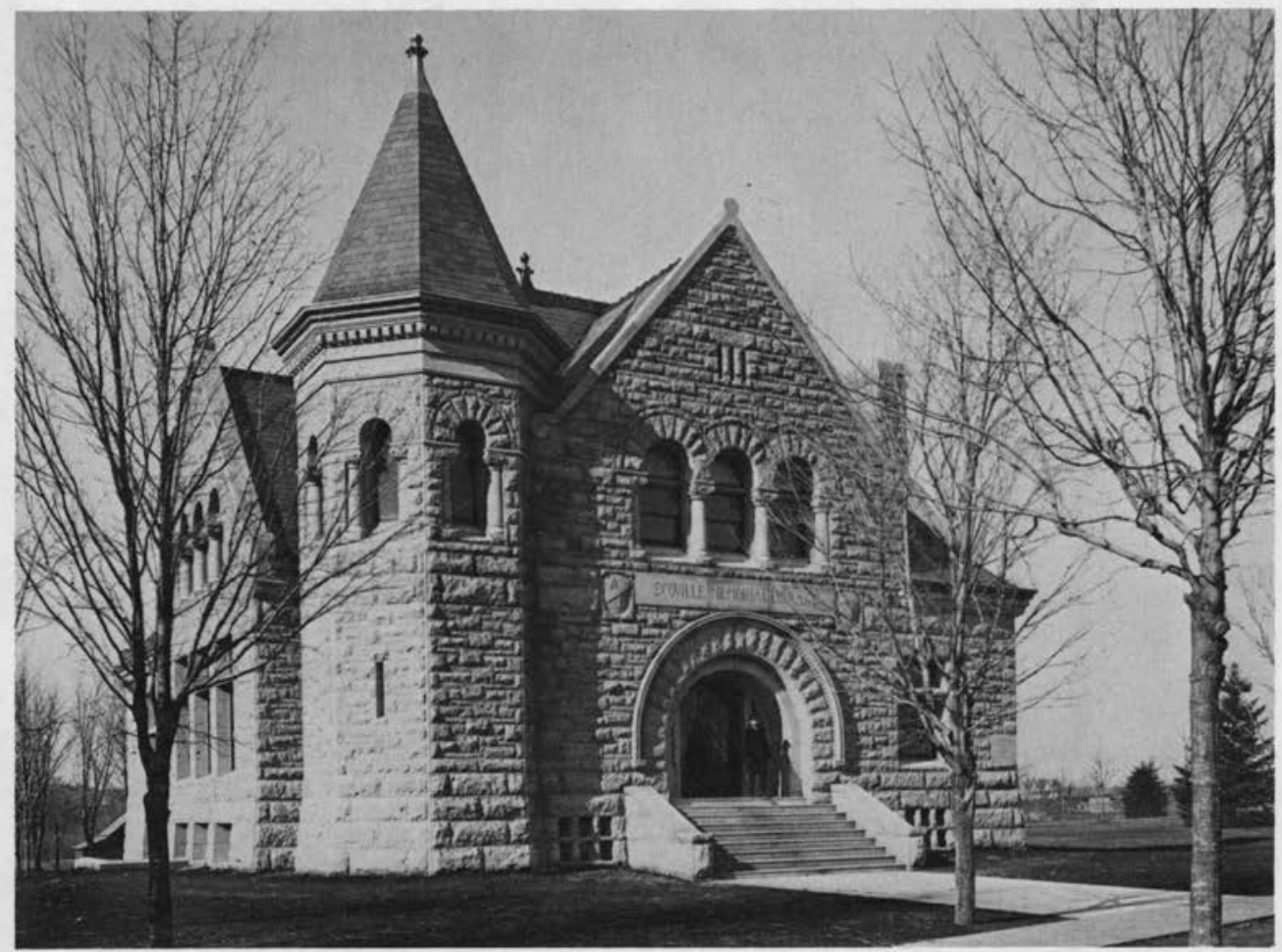

The Scoville Library, Carleton College

Carleton College Archives Northfield, Minnesota

other educational functions. The main floor provided a reading room and large book room only slightly set back from a central entry. The reading rooms were modern in design; the exterior, described as Italian Renaissance or Romanesque, was relatively simple, compared with most of its Gothic and highly ornamented predecessors.

1895 was a banner year for smaller libraries, with Ohio Wesleyan $(\$ 50,000)$, Kansas State University $(\$ 75,000)$, Wabash College $(\$ 35,000)$, and the University of Nebraska $(\$ 75,000)$, all funded and completed that year. In each case nonlibrary functions filled important parts of the new "libraries," in some more than half of the new space.

One small college, Carleton, and two universities, City College of New York and Western Reserve, occupied new libraries in 1896 . Of these only the City
College of New York had grandiose plans. The great ones came to the fore in 1897. Princeton built a large addition to its already widely known Green library.

Columbia built one of the largest libraries of its time. Planning began in 1894, but the building was not dedicated until October 4, 1897. The dominant influences of that time are abundantly evident in its description by its planners;

In style it is purely classic, with a line of columns across the front, and a low dome somewhat similar to that of the Pantheon, and reminiscent of the administration building of the Columbian Exposition. Entering from 116th Street, one will ascend by a great flight of steps 330 feet broad, to the first terrace, paved with stone, and then by successive flights to the portico of the li- 
brary, at a distance of 205 feet from the street, the plan of this grand entrance being somewhat similar to that of the capitol at Washington. The front of the building will consist of a portico with 10 Ionic columns, reached by a flight of steps. ${ }^{8}$

The University of Illinois made a start at this time, announcing its funding and plan in 1895, and the building was dedicated in June 1897. The design was by then more standard, with service and reading areas on the broad front and a multitier bookstack to the rear. Illinois then had 30,000 volumes, and the library was built to accommodate 150,000 . Someone, even that far back, had the wisdom to know what kind of a library Illinois was to become.

To characterize this period as experimental is perhaps misleading. It was experimental only in seeking ways in which architectural expression of earlier periods could be superimposed upon space that might serve library purposes. Within the design and skin of the building the input of the librarian was devoted almost entirely to fitting necessary functions into the kinds of space assigned for library use and resolving some of the difficult problems imposed by architectural design. It should be remembered also that at this stage of institutional development, scarcely any library was planned exclusively for library use.

The Columbia University library initially housed the president's office, offices for his secretary, the assistant secretary, the faculty of political science, the faculty of philosophy, the law library, and lecture rooms. Illinois devoted the library's second floor to the president's suite of rooms, the trustees' rooms, and the registrar and business agent's headquarters. Many of these libraries served also as art galleries, museums, lecture or assembly halls, faculty offices, and seminar rooms. ${ }^{9}$

Even the small college libraries, afflict- ed by the limited support of that period, followed this pattern. A description of the new library at Wabash College stated "the second story contains an art gallery, a statuary hall, and a trustee's room." The first separate library building at the University of North Carolina also served as the university ballroom at a time when dancing was seen as an essential function in the academic community. The Lincoln University library (1898) in Pennsylvania, which cost “over $\$ 20,000$," reported "an interesting feature of the building is the bowling alley in the basement for the use of students."

In this period (1876-1900) some progress was made in physical planning. Librarians began to make their operational needs known and better understood. Staff working spaces began to appear. Separate book rooms or bookstack structures were often included. Greater provision was made for readers, as well as for books. Although the lofty reading rooms persisted, the gallery concept was less frequently planned. There was, however, no progress of any visible consequence in coping with the strong compulsion to build the grandiose, the traditional, or with the near-complete domination of the aesthetic over the functional.

\section{Evolution}

A useful theory of academic library building evolution was developed by Helen Reynolds for university libraries $;^{10}$ it is equally appropriate for smaller academic libraries. Beginning with 1890, she outlines three distinct periods, based upon campuswide architectural planning. Beginning with the Romanesque, she characterizes the time from 1893 to 1917 an eclectic period and from 1917 to 1939 as the modern period.

My own division is more simple and is based upon library planning alone. In it, the time before 1900 can only be designated "primitive," no matter what the 
size or character of the institution. I would describe the period from 1900 to 1945 as "evolutionary," notwithstanding the obvious conclusion that everything continues to evolve. In those forty-five years, academic libraries, librarians, and their architects reached a thoroughgoing understanding of their respective functions and what was needed to serve them. In the period since 1945 most developments in library planning have resulted more from increased numbers and size, than from changes in function.

By 1900 many engineering problems had found better solutions. Gas light had been replaced by electricity. Heating and ventilation had been improved somewhat. Steel frame construction was better understood, leading to new designs for bookstacks. While these environmental needs were gradually being resolved, at least three other major problem areas came to dominate this period. Foremost was the steady increase in the numbers of those who used the libraries. This was the time when many private and public colleges and universities came into being. The establishment of the land grant colleges and many new state universities brought the cost of higher education to an easily attainable level. This also was the period out of which came the universal conviction that education was the undeniable right of every individual.

The swift increase in student numbers, proportionate increases in faculty, and the inevitable changes in educational methodology made an ever-growing place for the library in the academic community. Growing production of books, journals, and other library materials demanded better and larger spaces for holding as well as access to the collections. Finally, recognition of the need for working space for staff became a fully accepted part of library planning.

Reynolds described three basic design patterns of early libraries:

(a) a linear arrangement with the reading room and storage element arranged in a line to form a rectangular group; (b) a centralized plan which had a square or octagonal reading room around which the other elements of the library were distributed, making a ground plan of a Greek cross, usually surmounted with a dome; (c) an angular arrangement of two wings, one containing the reading room, the other the storage element, making a ground plan of an $L$ or $T$, sometimes with other wings added to form an I or U.11

Smaller college libraries often departed from these types, since they were so often subjected to the use of part of their library building space for extraneous academic functions. In later libraries of this period, as the numbers of both users and collections increased, buildings were built or planned to accommodate large multiples of their known numbers, resulting in the rapid spread of the compact plan, usually a rectangle, sometimes broken internally by light wells, or various configurations based upon the T. The bookstack was usually to the rear, or it formed a central core. Also as the volume and variety of functions increased, the larger libraries often moved the public service areas, reading rooms, and circulationcontrol area to the second floor, leaving the noise of the entrance and heavy traffic to the first level. Those which also had graduate programs and research responsibilities went up to a third floor for seminars, studies, and group study areas.

A few libraries tried the stack tower, but both aesthetic and practical considerations limited its adoption. Many libraries used multitier stacks of ten or more levels, usually contained within the building structure, either central or at the rear. Another concept which had only modest success was the browsing room, a recreational reading area; it did 
not endure in later planning.

The University of Texas (1911) is a good example of the $T$ design, with the second floor service area and a stack tower central and to the rear. The Columbia University library is offered as the prototype of the compact plan with a core stack, surrounded by reading rooms and service functions and using the resulting common floors as main service areas. This second-floor service concept was common even in the smaller college libraries, since the entrance level frequently was planned to accommodate other college functions such as the president's office, trustees' room, registrar, or an auditorium.

Examples of this period in the college group generally fall in the range of $\$ 200,000$ to $\$ 250,000$, with a notable exception, Dartmouth, which cost
$\$ 1,200,000$ and Vassar, at $\$ 500,000$. Some good examples of the types of planning described can readily be selected from the following chronological list: Radcliffe (1905), Vassar (1905), Amherst (1917), Williams (1923), Emory (1926), Hendrix (1927), Knox (1928), Dartmouth (1928), Reed (1930), Coe (1931), Agnes Scott (1936), Denison (1937), and Franklin and Marshall (1938).

Among many in the university group, typical of this period were Chicago (1912), Harvard (1914), Stanford (1919), Michigan (1920), Minnesota (1924), Alabama (1925), Washington (1926), Duke (1927), Illinois (192629), North Carolina (1929), Yale (1931), Rochester (1931), Southern California (1932), Atlanta (1932), Columbia (1934), and Oregon (1937).

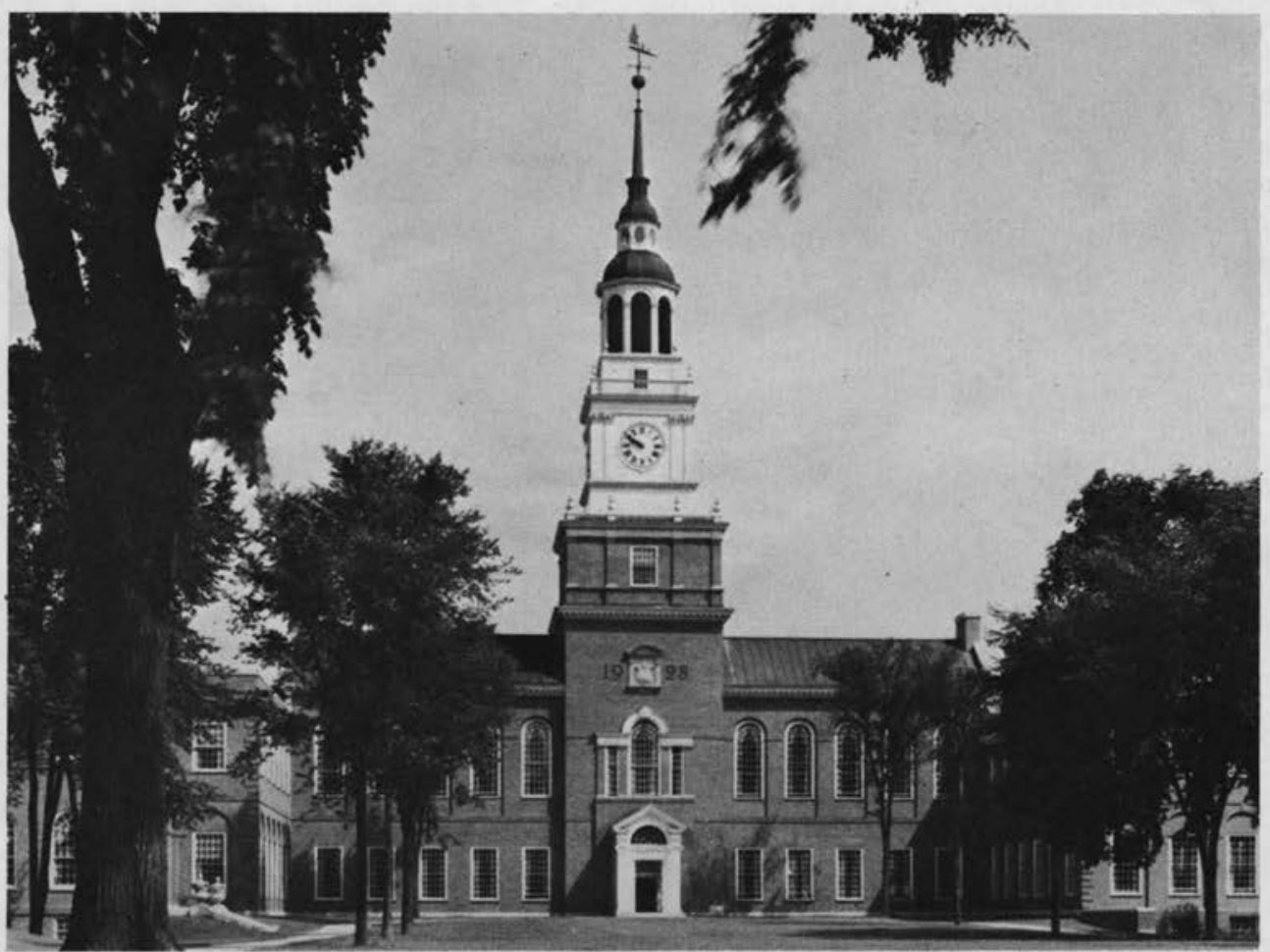

Dartmouth College Library

Dartmouth College Library Hanover, New Hampshire 


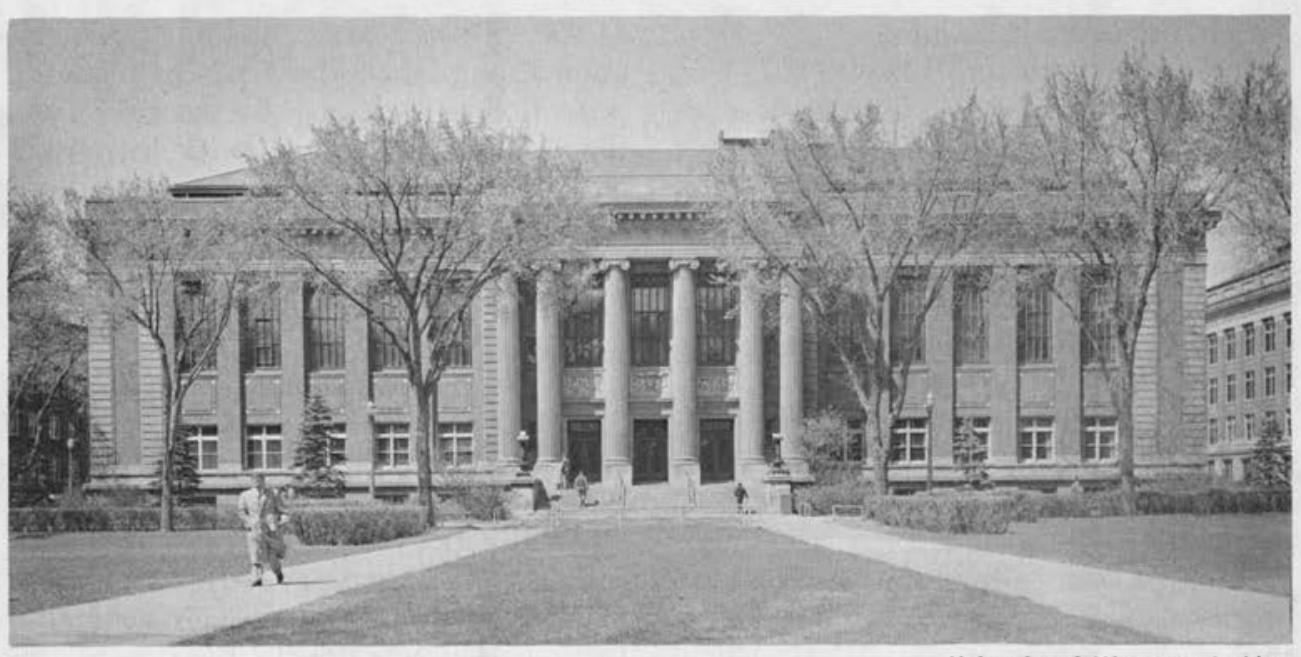

University of Minnesota Library

University of Minnesota Archives

Minneapolis, Minnesota

By the end of the 1930s, university library design had become so standardized that for many the external aesthetics constituted their only distinguishing difference. The exuberant growth that was to follow World War II had not yet arrived, and although the numbers were larger, there was a fairly consistent pattern of size for comparable institutions. This period ends with 1945 , due consideration being given to the great variations in development resulting from a long depression and the subsequent World War. Academic development plateaued (at least for library planning and building), and a period of relative inactivity preceded the final third of the century when library development and planning attained their highest apparent level.

\section{The Postwar Years}

The factors determining the character of academic library planning of the last three decades were abundantly evident, proliferating rapidly, and well identified by competent library planners. Early in this final period of our century, a University of Chicago Graduate Library School Institute, 1946, took as its subject Library Buildings for Li- brary Service. In the introduction to the published record, Herman Fussler wrote:

There is an early era in library design that might be called the period of improvisation, followed by the monumental or ornamental era as revealed in most of our existing library buildings today. It has been only very recently that the monumental type of building has been subjected to serious and critical scrutiny. Beginning with the late nineteen thirties there began to appear a few library buildings . . . that showed distinct signs of functionalism in their design, that were attractive, yet completely lacking in ornamental and monumental characteristics. It seems reasonable to expect that these few buildings, together with the delays in construction caused, first, by the economic depression of the thirties and, then, by World War II have placed us at the threshold of a new era in library building design that will reveal a major preoccupation with function rather than with traditional architectural style or ornament. ${ }^{12}$

Fussler's characteristic prescience was good for twenty years. From 1945 to 1965 the steadily growing proliferation of ever more and larger educational institutions was matched by the growing 
competence of librarians and architects in planning library facilities to serve their part of the enterprise. It was in this period that the productive series of conferences of the Cooperative Committee on Library Building Plans were held. Many articles and books appeared, and virtually every new library building was reported, explained, dissected, and reviewed in the library press..$^{13}$ Every librarian who became responsible for planning his or her new library became an expert, if not a consultant, on academic library planning.

Since more library buildings were being planned, architects became more involved. Many of them accepted the new technical competence of the librarians, and some of them, having designed a number of libraries, became increasingly understanding of the functional requirements of such structures. Program documents were generally prepared, and often thoughtfully used by the architect. There was a preoccupation with function, and the results are apparent in many good libraries of those years. By 1965 the modular design became the dominant central pattern of new library buildings. ${ }^{14}$

Although the numbers and variety of academic libraries of this double-decade were not as great as in the final ten years of the century, they are far too numerous to list or comment completely. Some had better reporting than others and deserve mention; many equally deserving were reported only in local or regional sources. ${ }^{15}$

The Lamont Library, the prototype of the undergraduate library, was completed in 1949. Its conception was widely debated then and is still controversial. The University of Michigan occupied its undergraduate library in 1958.

In the small-college field a large number of new libraries were built. Bucknell (1952), Wheaton (1953), Claremont (1953), Harding (1954), Carleton (1955), Antioch (1955), DePauw
(1956), Cornell (1957), Drury (1959), Hampden-Sydney (1961), Beloit (1962), Adelphi (1963), Earlham (1963), Simpson (1964), Bowdoin (1965), AshevilleBiltmore (1965), St. John's (1966), Chabot (1966), are only a few of numerous examples.

Far more new libraries fall into a general category of medium-sized institutions, comprising the fast growing list of colleges and universities just beginning to experience the shock of rapidly expanding enrollments and the concomitant need for larger physical plants. Among many others deserving equal mention are Rice (1949), MIT (1950), Southern Illinois (1954), Louisville (1955), North Carolina State (1955), Western Reserve (1959), Rutgers (1957), Louisiana State University (1958), Drexel (1959), Washington University in St. Louis (1962), Nevada (1962), University of South Florida (1961), Delaware (1963), Tufts (1965), Oral Roberts (1966), and Arizona State (1966).

Of the large universities the list is more limited, but a few merit particular attention. In 1948 the great Princeton library was completed, one of the finest of its time. In 1953 both Georgia and Georgia Tech occupied extensive new buildings. Nineteen sixty marked the completion of the Cornell University library. Nineteen sixty-four was a notable time for Johns Hopkins and Notre Dame, each having its distinctive place in the design of large libraries. UCLA occupied the first large unit of its library in 1964.

A few libraries of that period were distinctively different because of the nature of their parent institutions. Four of these, Bennington (1960), Barnard (1960), Simmons (1961), and Douglass College (1961), were in predominantly women's institutions. One was a military academic library, the Air University (1955), and one a rare-book library, the Beinecke at Yale (1963). 
326 / College \& Research Libraries • July 1976

TWO GENERATIONS OF LIBRARIES

AT WASHINGTON UNIVERSITY

ST. LOUIS, MISSOURI

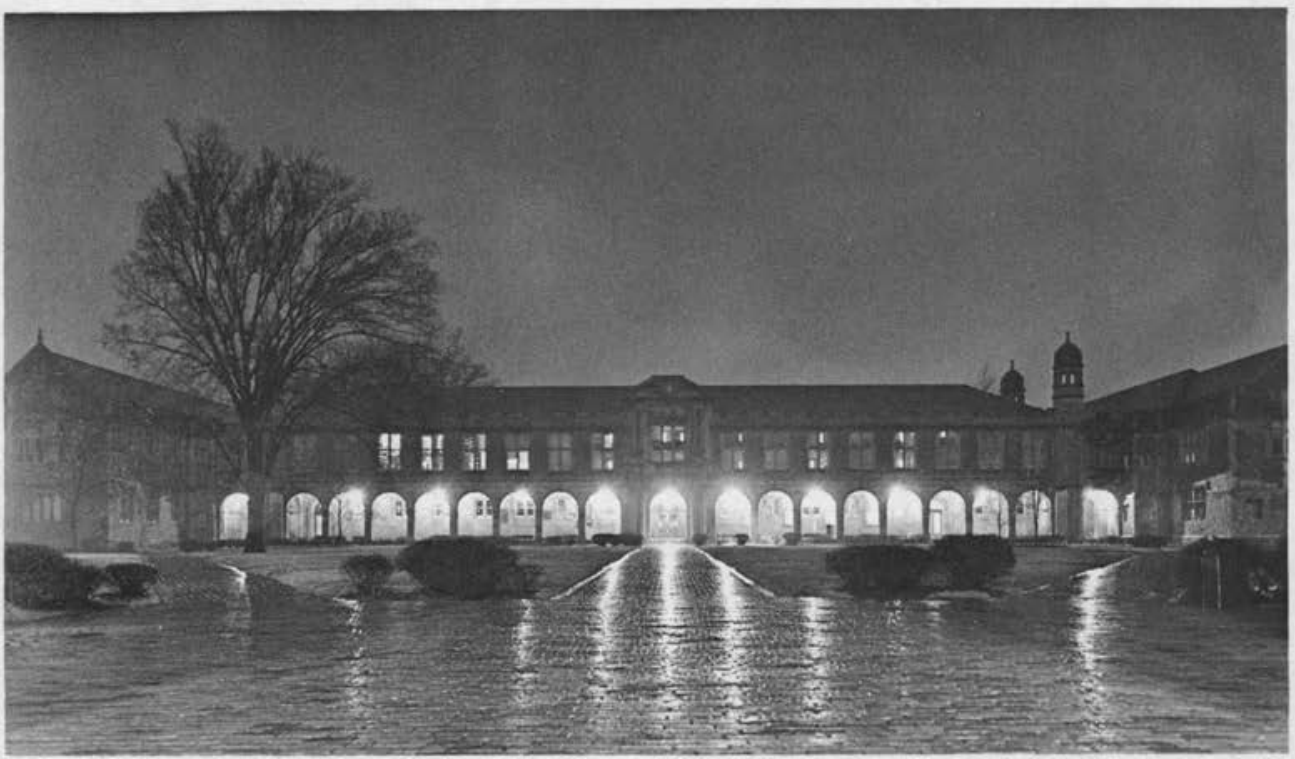

Ridgley Library, 1905-1962

Washinaton University Library

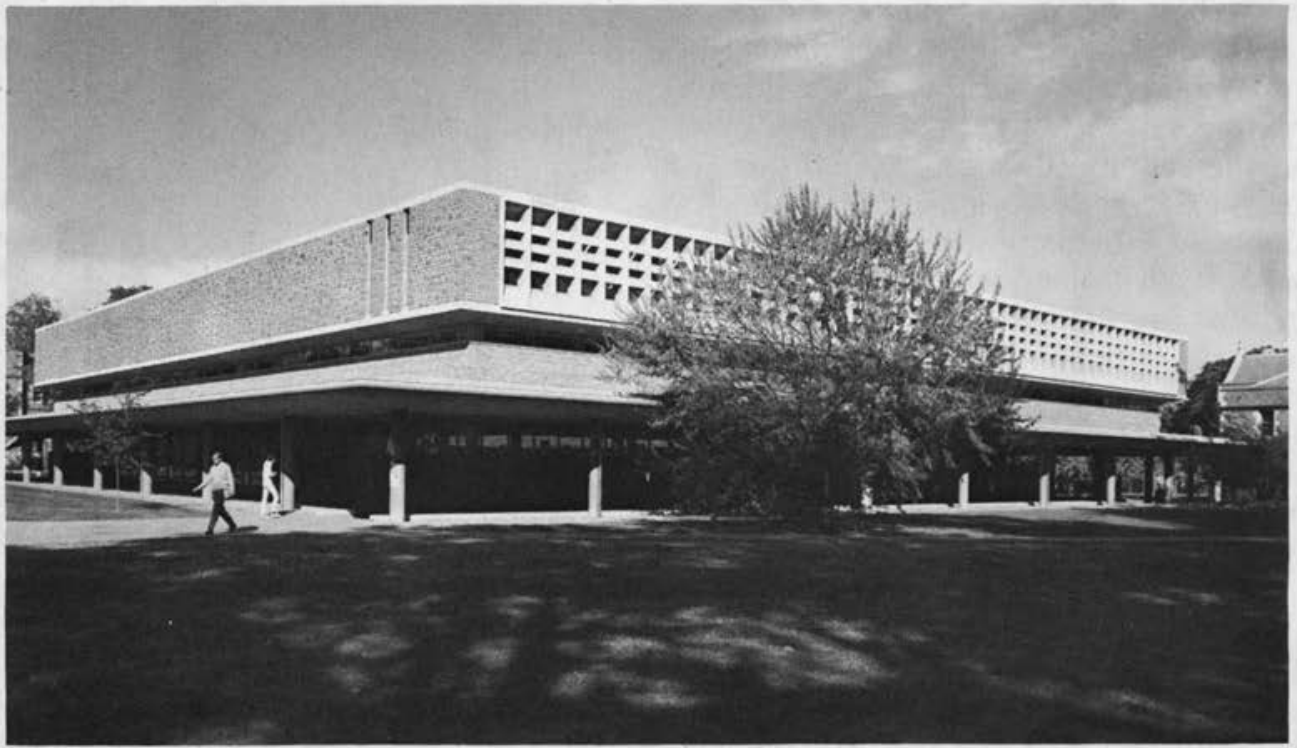

John M. Olin Library, 1962

Washington University Library 
It may be useful also to note a few of the libraries which were enlarged by sizable additions. Duke University in 1950 and its neighbor, the University of North Carolina in 1952, followed this pattern. Ohio State also built an addition in 1952, and Kent State did so in 1958. The growth rate accelerated so swiftly in this period, however, that most libraries were planned as completely new units on a very grand scale.

Compared with libraries of earlier periods, most of these libraries met the program requirements for the functions then recognized. Many of them found felicitous aesthetic response in skin or design treatments reflecting innovative use of new materials, uninhibited by traditional architecture of any earlier period. The major criticism of many of these new libraries grew out of the failure to read far enough into the future of the library's functions and academic change. ${ }^{16}$ Despite the then ample provision of planning information, decades of experience, and highly advanced technology, we seem to have reached the last decade still planning libraries that often prove to be inadequate. There were some successes, but time revealed more often than not that new buildings were inadequate for the rapidly changing academic world. In addition to running the full gamut of design, academic libraries changed in patterns of service. ${ }^{17}$

The separate undergraduate library came into its own, and professional and subject branch libraries again found new acceptance on large campuses. Internally, the old concept of the browsing room evolved into a wide range of types of reading and study spaces interspersed throughout the book stock areas. New kinds of service areas for computer operations, photocopy use and production, communication centers, and audiovisual facilities appeared ever more often in library planning. On many college campuses the library be- came a "learning resources center," while the librarian found a new title, as "dean of learning resources."

Thus the last decade of this centennial period began auspiciously with the full range of experience in methodology and materials, in the traditional and novel, and with powerful forces of change and new magnitudes of size to challenge the imagination. Federal funding was timely, recognizing the great stresses derived from increased enrollments and the explosion of information. Beginning with 1967, the annual record of academic library building clearly reveals the rapidly escalating pace of library building in our country. ${ }^{18}$ These and other individual library reports in many library publications now constitute the most extensive recording of academic library planning and construction we have ever known in our country.

In view of the vast resources available to planners in this decade, a prolific literature, decades of arduous learning, well-oriented and knowledgeable professionals (both librarians and architects), large and readily available funding, one might expect this ten-year period to reach the highest pinnacle of successful implementation of all that was good in the past record. The statistical data for these last ten years have been recorded as reliably as any such data collection can be made. It is by far easier to judge or make historical comparisons of measurable data than to interpret changes in quality, whether it be of planning or effectiveness. It may be even more difficult to project and predict future goals, however irresistible the pressure is to do that. For better or worse, we will naturally turn to our most recent experience to seek guidance.

In these past ten years, more, larger, and more-varied library buildings have been built than in the ninety years preceding $1966 .{ }^{19}$ We have had more than 600 new library projects in less than ten 
years. Many are over 200,000 square feet, and a major university administration now contemplates a probable new library cost of over ten million dollars with equanimity.

Design possibilities now include every variety in space, the high, the broad, or the deep. We have a tower nearly three hundred feet high (University of Massachusetts, Amherst), a number of libraries having vast acreage (Notre Dame, Indiana), and a number below ground level (Illinois, the Pusey at Harvard, Hendrix College). We have libraries where bodies of water are an integral factor of the design (Lyndon State, Loyola-Notre Dame, U.S. Naval Academy), and others where local materials and terrain have been ably incorporated in architectural design (Southern Utah, Indiana). We have many varieties of imaginative architectural design (Northwestern, California at San Diego, Clark, PMC College), good or bad, depending upon who is judging.

We continue to have a liberal infu. sion of design modes coming from other cultures, in buildings of Breuer, Aalto, Pereira, Netsch, Yamasaki. It would be patently impossible to enumerate all the good or bad in anyone's judgment; suffice it to say, there are many of each. Only time can tell which of these new libraries will be most successful. One is constrained then to speculate on the product of one hundred years of learning about library planning and on its usefulness for future planning.

One lesson we have certainly acquired from past experience is that nothing we do is static, and the speed of change in ever more swift. However great our concern for coping with this change, we are increasingly aware that library planning for an academic institution can only be as good as the planning for the whole institution and its place in that planning. Though we have learned this, we still have not only enduring and retrograde influences of the past, but the ageless legacy of human frailty and simple arrogance which can frustrate the best efforts of the able and earnest. ${ }^{20}$ Planning for any aspect of academic building often is also affected, if not determined, by economic or political factors within or beyond the institution. New technology has solved some troublesome problems of earlier years, but it has also created some new problems of its own. ${ }^{21}$

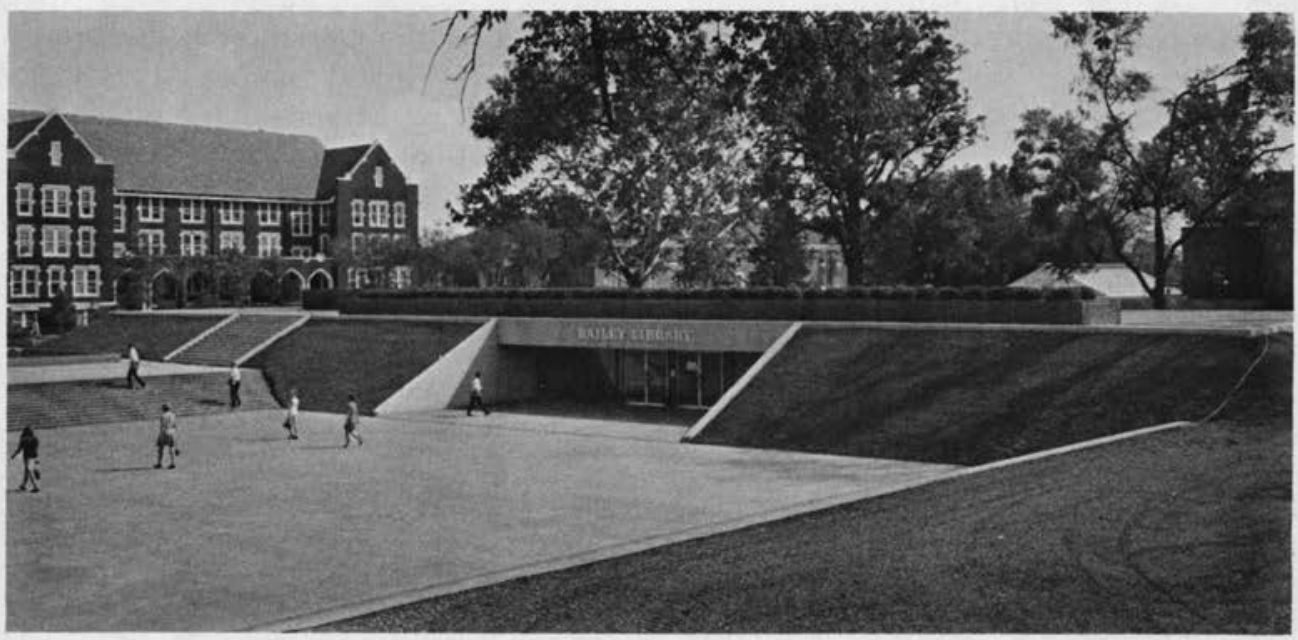

The Underground Library: Olin C. Bailey Library

Hendrix College Hendrix College, Conway, Arkansas 


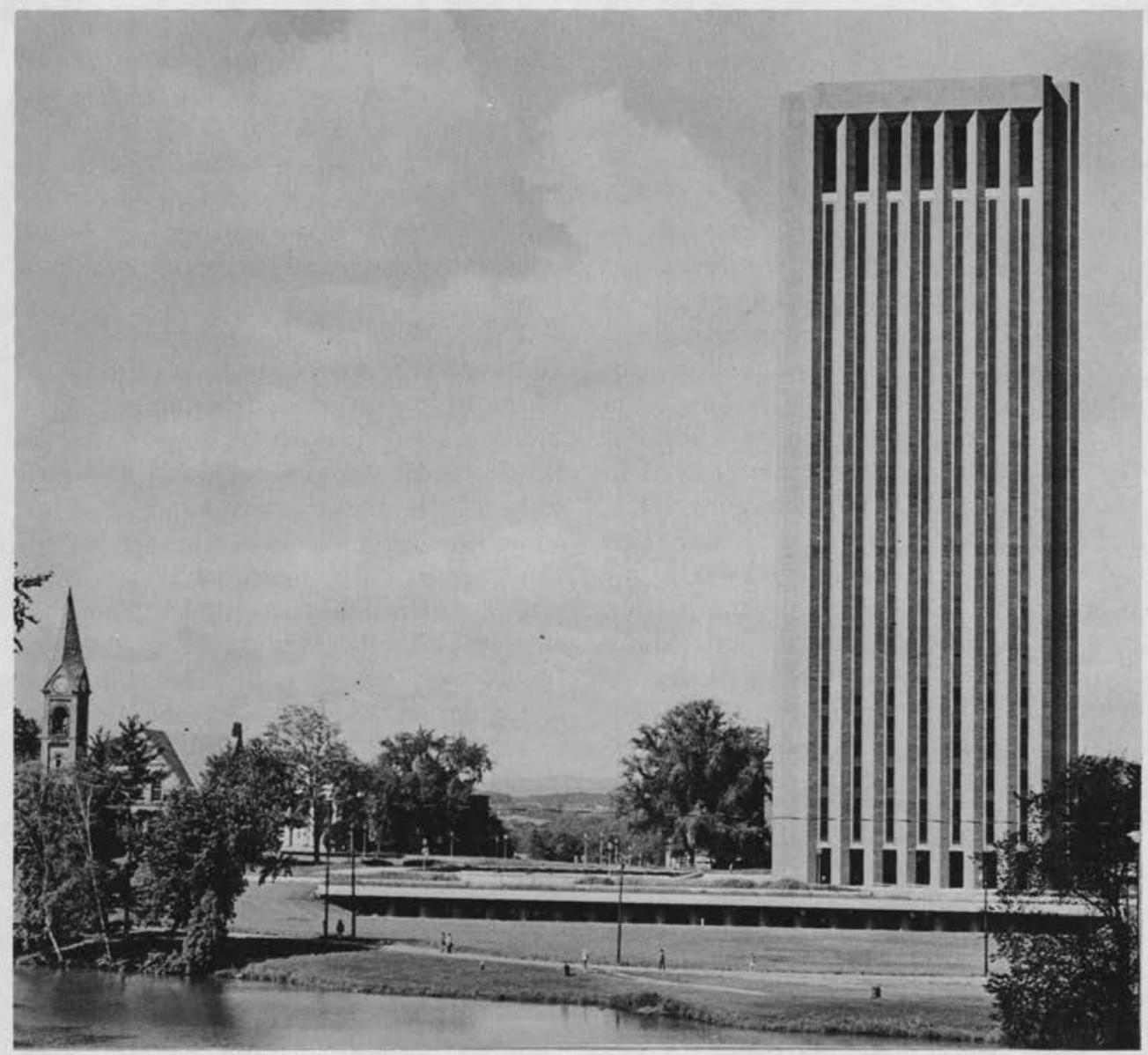

The Tower Library

University of Massachusetts

University of Massachusetts, Amherst

\section{ConClusion}

Any thoughtful review of a centurylong experience with academic library building and even casual awareness of current library planning must lead to the rueful conviction that though we have a large body of experience and considerable professional awareness, we may not have learned very much. We know a great deal about what is good and productive, yet every year we see some examples of design as benighted as those of a hundred years ago. We find libraries built tall, deep, or broad for reasons hard to comprehend. Even worse, we see new libraries planned for numbers, purposes, or goals not clearly established. How then have we grown, or even changed, in the past one hundred years? And what are the lessons we can garner from this century of experience?

We have grown larger; that much is certain. We build more libraries in one year now than the whole country had a hundred years ago. One of these modern libraries commonly holds greater resources than the entire list of libraries in 1876 .

We have made great advances in solving many of the vital issues in academic library building planning which plagued our peers a century back, yet 
many of the problems of 1876 are still with us today, despite the great claims of new technology.

In the early period we succeeded in establishing the function of the library in the academic community, and we began to move away from medieval design. In the second period we developed functional patterns for interior space and reached a high point in coordinated planning. Architects and librarians listened well to each other, and the functional requirements of libraries and their patrons were prominent in library planning. In the last period this trend has been reversed, and architects and architecture have reached a new low in matching good functional design with the architect's imagination. Many of our new libraries are now monuments again, but not in the sense of a hundred years ago. These are monu- ments to some architect's ego, and a disgraceful evidence of the low estate of the librarian who was unable to reorient this monumental waste. This is not to say that all are bad. Some excellent libraries can now be found in any state of our country. Some can also be found whose planning is little short of hopeless.

These, then, are the advances of the century. We now have a multitude of libraries on academic campuses. We know a good deal about how to plan libraries to fit our present goals and possibly a little about future needs. We are sometimes effective in working with administrators, architects, and the body politic in the detailed development of library building planning. We are usually not very effective in influencing the coordination of library resources and functions with the academic goals of

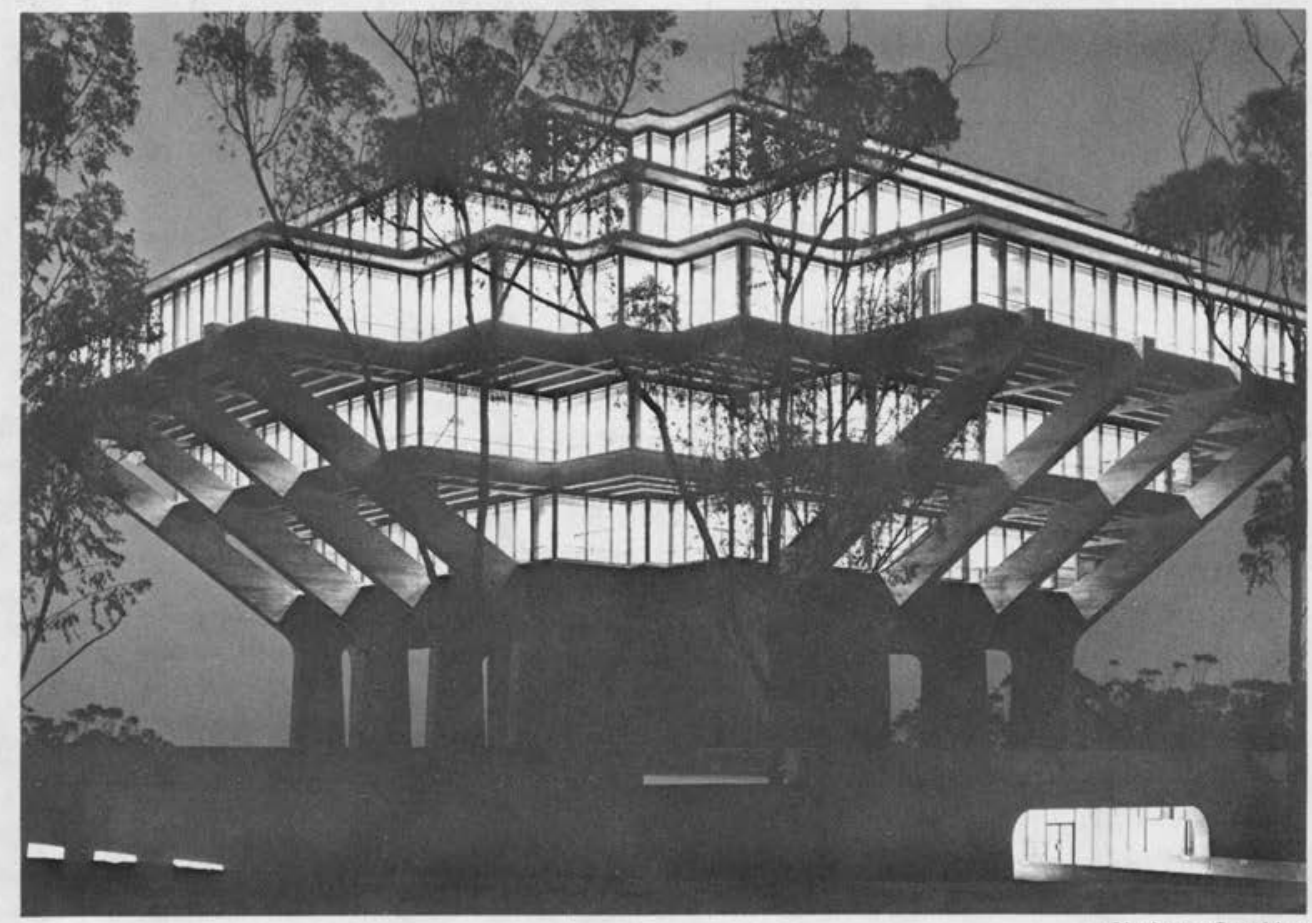

University Library

Glasheen Graphics University of California, San Diego 
our parent institution, even less with the reverse. It is readily apparent to all who now plan libraries that technology has not resolved our century-old difficulties of coping with light, heat, and ventilation. Many architects of our affluent time are again planning from the outside in, rather than from the inside out; they are quite naturally more interested in aesthetics than pedestrian engineering.

We are now entering a new century of library development, rich in experience, resources, and learning. We ought to be able to read out our earlier weaknesses or failures and readily recognize our singular successes. Ours is a swiftly changing world where every advance seems to bring with it new problems. Compared to the academic library world of 1876 , ours seems very large and complex. Since we cannot turn back time, we must bend all of our strength, our wisdom, and our judgment to understanding all that a century has given us to help make the century ahead a better one.

\section{REFERENCES}

1. Edward G. Holley, "Academic Libraries in 1876," College \& Research Libraries 37: 15-47 (Jan. 1976).

2. U.S. Department of the Interior, Bureau of Education, Public Libraries in the United States of America: Their History, Condition, and Management, Special Report, Part I (Washington, D.C.: Govt. Print. Off., 1876), p.125-26. The table is reprinted in Holley, "Academic Libraries in $1876, "$ p.20-21.

3. C. C. Soule, "Points of Agreement," $L i$ brary Journal 16:17-19. (Dec. 1891).

4. H. M. Utley, "Report on Library Architecture," Library Journal 15:12 (Dec. 1890).

5. Library Journal 13:331-32, 338-39 (Nov. 1888).

6. Normand S. Patton, "Architects and Librarians," Library Journal 14:159-61 (May-June 1889).

7. John E. Burchard, "Postwar Library Buildings," College \& Research Libraries 7: 118-26 (April 1946).

8. Library Journal 19:379 (Nov. 1894).

9. W. N. Chattin Carlton, "College Libraries in the Mid-Nineteenth Century," Library Journal 32:480 (Nov. 1907).

10. Helen M. Reynolds, "University Library Buildings in the United States 1890-1939," College \& Research Libraries 14:149-66 (April 1953).

11. Ibid., p.152-53.

12. Herman H. Fussler, ed., Library Buildings for Library Service (Chicago: American Library Assn., 1947), p.v.

13. David Kaser, "A Century of Academic Librarianship as Reflected in Its Literature," College \& Research Libraries 37:121-23 (March 1976).

14. Ernest J. Reece, "Building Planning and Equipment," Library Trends 1:143-44 (July 1952).

15. For a description of one year's product see Robert H. Muller, "Library Building Construction among Colleges and Universities, 1950," College \& Research Libraries 11: 259-61 (July 1950).

16. Ralph E. Ellsworth, Planning the College and University Library Building (2d ed.; Boulder, Colo.: Pruett Press, 1968), p.1-10.

17. Harry Sanders, Jr., "Design Fashions and Fads in University Libraries," Library Trends 18:120 (Oct. 1969).

18. Jerrold Orne, "Academic Library Building in 1967," Library Journal 92:4345-50 (Dec. 1, 1967), and continuing in the December 1 issue of Library Journal for each subsequent year.

19. Sanders, "Design Fashions and Fads in University Libraries," p.120.

20. Ralph E. Ellsworth, Academic Library Buildings (Boulder, Colo.: Colorado Associated Univ. Press, 1973), p.10-11.

21. Donald C. Davidson, "Significant Developments in University Library Buildings," $\mathrm{L} i$ brary Trends 18:125-37 (Oct. 1969).

Jerrold Orne is professor emeritus,

School of Library Science,

University of North Carolina

at Chapel Hill. 